\title{
The Effectivenes of Inquiry Chart Strategy In Teaching Reading Comprehension of Report Text Towards The Eleven Class Students At SMAN 12 Padang
}

\author{
Tesi Astria \\ Language Education Program, State University of Padang \\ Correspondence email: tesiastria47@gmail.com
}

\begin{abstract}
Abstrak. Penulisan artikel ini bertujuan untuk menemukan keefektifan dari penggunaan Strategi Inquiry Chart dalam pengajaran pemahaman membaca teks report terhadap siswa sekolah menengah atas (SMA). Penelitian ini adalah penelitian eksperimen dengan menyelenggarakan Tes Penempatan yang digunakan untuk memilih sampel dan Post-test yang digunakan untuk mengukur pemahaman membaca siswa dalam teks report setelah perlakuan. Populasi penelitian ini adalah kelas IPA sebelas di SMAN 12 Padang tahun ajaran 2017/2018 yang terdiri dari empat kelas dengan total siswa 135 siswa. Sampel penelitian ini dipilih dengan menggunakan cluster random sampling. Sampel penelitian terpilih adalah kelas IX IPA3 sebagai kelas ekperimental (34 siswa) dan kelas XI IPA4 sebagai kelas control (34 Siswa). Dalam proses pengajaran, peneliti menggunakan Strategi Inquiry Chart pada kelas eksperimen dan Strategi Small Group Discussion pada kelas kontrol. Instrument yang digunakan untuk mengumpulkan data dalam penelitian ini adalah tes kemampuan pemahaman membaca. Dalam menganalisis data, peneliti menggunakan uji T. Hasil penelitian menunjukkan bahwa: Strategi Inquiry Chart memberikan hasil yang lebih baik terhadap kemapuan pemahaman membaca siswa dalam teks report dibandingkan dengan Strategi Small Group Dicussion, dengan $t_{\text {observed }}=3.823>t_{\text {table }}$ $0.05=1.668$, sehingga Ha diterima. Dengan demikian, dapat disimpulkan bahwa Strategi Inquiry Chart efektif untuk digunakan sebagai strategi untuk mengajarkan pemahaman membaca report teks di SMAN 12 Padang.
\end{abstract}

Kata Kunci: Pemahaman Membaca; Strategi Inquiry Chart; Teks Report

\section{INTRODUCTION}

Reading is one of the four basic skills that should be studied by all students in language learning. It is highly needed by the students to support the progress of their study achievement. By reading, the students can get much information to expand their knowledge. However, the students need comprehension in order to be the successful readers. Reading comprehension is a process of students understanding toward reading text to get some information. As stated by Snow (2002) "reading comprehension is a process in which the readers extracts information from a written text and construct meaning by means of an interaction and involvement with the text". It refers to the specific abilities that enable a student to read and understand the text with independence, which are shaped by their prior knowledge, experience, attitude, and language community which is culturally and socially situated. Thus, reading comprehension is a language process that needs one's ability to understand the information that is provided in the text.

In 2013 curriculum, reading skill is also determined as one of basic competencies in English lesson. At Senior High School, Noh (2013) states that "the goal of teaching reading is to enable students to comprehend social functions, generic structures, and language features of the texts". For that reason Senior High School students are taught to comprehend two kinds of texts namely functional and monologue texts. For the eleventh class of Senior High School, the students are expected to be able to comprehend the content of various types of text. One kind of the texts is report text. It is a text which presents information about something and results of systematic observation and analysis which used as a way to gain a better comprehending about a living or non living subject. In English syllabus, Report text is stated in point 3.6 and 4.9. First, the students are able to analyze text structure and linguistic features to conduct social function of report text by telling and asking about short and simple factual report text of people, animals, things, natural, and social phenomenon, related to another lesson in eleventh grade. Second, the students are able to comprehend oral, written and simple factual report text of people, animals, things, natural and social phenomenon, related to another lesson in eleventh grade. It means that, report text contains of information about something that can add the students' knowledge.

In fact, the students of Senior High School still got some difficulties in reading comprehension of report text. As found by Rahmad (2017) "the students are in trouble to answer the questions of identifying main idea, getting general information and detailed information, acquiring new English vocabulary, words reference, synonyms and antonyms belonging to report text. Previously, Hanifah (2014) also discovered some students' difficulties in report text. "First, the students were difficult to identify the information in generic structure of report text like general classification, and description. Second, the students did not really understand about language features on report text. Third, the students were lack of vocabulary. Fourth, the students had difficulty to understand the implicit meaning and conclusion of the text". Additionally, Rahmi (2014) explained that "students' difficulties in reading comprehension of report text are also caused by lack of background knowledge such as related idea, linguistic elements, and the structure of the text". In this case, they were not capable enough to connect their mind with the reading topic being taught that caused them difficult to comprehend the text well. Consequently, these difficulties will affect to students' score in reading comprehension.

To solve the problems, the teacher should use the effective strategy to help the students to comprehend what they had read easily. It is reasonable enough to think that the appropriate strategy selection in teaching 
reading comprehension is considerably important. As explained by Malena and Coker (1987) quoted by Crilly (2002) that "the English teachers need to provide students with concrete strategies in approaching reading tasks". In this process, the teacher should find an appropriate strategy in teaching reading comprehension in order to help the students to be easier in comprehending the text. It is not a simple matter; because the teacher has to be able to create a lot of activities, which it is not only increase students' achievement in reading comprehension, but also develop the students' learning motivation.

Based on preliminary study at SMAN 12 Padang, English teacher at the eleventh class has implemented a cooperative strategy in teaching and learning process of reading comprehension, such as Small Group Discussion Strategy. It is a language teaching strategy in which the teacher divides students in the class into several small groups. As stated by Ur (1996) that "a small group discussion consists of three to five students in studying, practicing, or discussing a material or a subject in order to reach goal". Besides being able to exchange the ideas, students also can enhance cooperation and togetherness in solving the problem they encountered during the processing task. In addition, Brookfield (1990) in Rahmat (2017) mentions some the advantages of Small Group Discussion Strategy. They are to engage students in exploring a range of perspectives and discovering new perspectives, to increase intellectual ability and to encourage active listening, to increase students' interest and involvement with a topic, to show students that their opinions and experiences are valued, to help develop a sense of group identity, to encourage democratic habit s such as valuing participation, respect for others' opinions and tolerance of diversity, the Students have opportunity to responsibility appropriate their ability, the students can improve their ability to lead and be lead by, and group is excellent way to discuss and work together. Besides, Brookfield (1990) in Rahmat (2017) also mentions some the disadvantages of Small Group Discussion Strategy. They are group work often involved smart students only, this strategy need differ arrangement sit and differ teaching strategy too and successful strategy of this group work suspended to ability students to lead the group or work alone. Briefly, we can say that Small Group Discussion strategy can be an effective learning situation, in which the students will be involved actively, because it gives students an opportunity to share what they read.

In applying this strategy in the classroom, the teacher divided students into some small groups and explained type of the text first. Then, the teacher asked the students to read the text, and answer several questions related to the text. Last, the teacher asked students to discuss about main idea, general and specific information of the text, and finding the meaning of difficult word in their group. However, the result was not as good as the teachers' expectation. The teacher cannot able to engage most of the students to involve actively in learning reading comprehension activities. Even, there were only the dominant students that follow discussion activities well. Therefore, reading comprehension achievement of the eleventh class was still un-satisfied. Anna (2013) also found some problems that normally occurred during the implementation of Small Group Discussion Strategy. Firstly, students are unprepared. Secondly, naturally quiet students do not participate. Thirdly, some students dominate the conversation. Fourthly, students may share inaccurate information. Fifthly, it is hard for the teacher grade. Here, we can see that Small Group Discussion Strategy on the students' side that is used by the teacher may not give advantages for students' reading comprehension achievement, because it can not suitable with students' condition in learning.

Actually, there are many strategies which can be applied in teaching and learning process of reading comprehension that can help students to comprehend what they had read easily. One of the strategies is Inquiry Chart Strategy. Pugalee (2015) states that "Inquiry Chart is a strategy that help students to generate questions related to a topic and identify what is already known about the topic and organize information that comes from multiple content area sources". Inquiry Chart strategy enables the students to gather information about a topic from several sources. The teacher support the students to generate some questions that will be used as the quideline in identifying information of the text. The students will learn to active their prior knowledge before they have reading. It will be easier for students to know information of the text, because the concept is related to their life. Inquiry Chart Strategy will give students the bridge between what they already known and what they do not know about the text. The students will think critically by integrating what they have already known about the topic and the information that they found in the text. Through this activity, the teacher will create the interactive process by giving the students an opportunity to do inquiry in comprehending a text, especially report text.

Furthermore, there are some advantages of using Inquiry Chart Strategy towards students' reading comprehension that explained by Buehl (2014). First, as students become more independent, they can develop individual I-Chart that focus their inquiry and organize their notes. Second, the students can generate a greater number of ideas from each member of group. Third, each member has chance to read some ideas of their mind on a paper, then group discussion will discuss the ideas, until they get the result. Fourth, the students have chance to share their opinions about a topic in discussion process. Fifth, the students confront the issue or problem through using problem solving in discussion. Then, the groups prioritize ideas democratically. Six, the groups are provided to explain about their product in written report. Seventh, this strategy fosters critical thinking and strengthens reading skills. While, according to Stewart and Rivera (2007) there are also some disadvantages for using Inquiry Chart Strategy in learning process. First, it does not work for all science topics. Second, it requires more planning, preparation, and responsiveness from the educators. Third, educators must be skilled in helping students learn the 
art of asking a good question. Fourth, it requires more class time and may be less able to meet goals of standardized testing. It can be understood that Inquiry Chart Strategy can serve an evaluation tool for how much a student has learned about a topic. Inquiry Chart Strategy teach students to have the goal in learning reading. They have pretension to finish their task well cooperatively. Additionally, it also habituates students to prepare themselves in comprehending a text. But, the teacher should consider about topic, time and preparation of using Inquiry Chart Strategy in order to achieve better result in learning reading comprehension.

The study about using Inquiry Chart Strategy in teaching reading comprehension of some texts had been conducted by some researchers. First, Pariska (2013) entitled "the effect of Using Inquiry Chart Strategy toward Students' Reading Comprehension in Report Text of The Second Year Students at Daarun Nahdhah Thawalib Bangkinang". She found that the students who are taught by using Inquiry Chart Strategy have higher reading comprehension score in report text, than the students who are taught without using Inquiry Chart Strategy. It means that, there was significant effect of using Inquiry Chart Strategy in report text of the second year the students at MA. Daarun Nahdhah Thawalib Bangkinang. Second, Ciptoharmi (2014) entitled "The effect of Inquiry Chart toward the Tenth Grade Students' Reading Comprehension at SMAN 7 Kediri in Academic Year 2014/2015". She had focus on news item text. In her research, she found that Inquiry Chart Strategy is very significant for the students of SMAN 7 Kediri. Such as; he can understand the text, improve the vocabulary, find the characteristic of news item text, identify the main idea and topic of a text, identify the detail information of a text; they are also more active in learning English especially in reading lesson and make a conducive class in teaching and learning process. Finally, she concluded that Inquiry Chart Strategy gives a better result in reading comprehension. Third, Andriyani (2014) "Teaching Reading by Combining Inquiry Chart and Dictogloss Strategies for Grade IX at Senior High School 16 Padang". This research focused on recount text. She found that the teacher can combine Inquiry Chart and Dictogloss Strategy in teaching reading of recount text for Senior High School, in which the students are more active, effective and efficient in reading comprehension activities. From the result of these researches, it could be seen that Inquiry Chart Strategy gives effect on students' reading comprehension.

On the basis of some researches above, the researcher was interested to use Inquiry Chart Strategy in teaching reading comprehension of report text at SMAN 12 Padang. It was grounded to teachers' explanation that she have not yet used Inquiry Chart strategy in teaching reading comprehension and students' reading comprehension of report text at SMAN 12 Padang was also still not good enough. Therefore, the researcher choose report text as a genre of reading text to be researched on reading comprehension in this research. To be different from the previous research, the researcher would see whether application of Inquiry Chart Strategy was more effective than the teaching strategy that was usually used by the teacher in reading subject, namely Small Group Discussion Strategy.

Based on those explanations, the purposes of this research is to find out whether Inquiry Chart Strategy produces better result towards students' reading comprehension of report text as compared to Small Group Discussion Strategy.

\section{METHOD}

This research belongs to quasi experimental research. It was used because using this strategy did not disturb the process of teaching and learning activities. Gay and Airasian (2000) states "the quasi- experimental research is non- randomized. Therefore, the subject could be given the treatment in their regular schedule as usual. Both of the classes got the same material, length of time and the same teacher. The researcher used two classes' namely experimental class by using Inquiry Chart Strategy and control class by using Small Group Discussion Strategy. Then, this research would determine the effect of both strategies on dependent variable namely reading comprehension.

The population of this research was Science Class Eleven of SMAN 12 Padang in academic year of 2017/ 2018. The total numbers of all students in Science Class Eleven were 135 students. There were four science classes namely XI IPA1 (32 students), XI IPA2 (35 students), XI IPA3 (34 students), and XI IPA4 (34 students). The samples of this research would be selected by using cluster random sampling. Some procedures would be done before selecting the sample of this research. First, the students in four classes were given placement test to measure their reading comprehension, because the characteristics of the sample in experimental research design must be same before the researcher gives the treatment. Second, Average score of students' reading comprehension would be calculated. Third, the normality and homogeneity of reading comprehension score would be calculated by using statistical Product and Service Solution (SPSS 18) which the data used KomolgorovSmirnov test. The result of students' reading comprehension for placement test can be seen in the following table:

\begin{tabular}{|l|c|c|r|c|}
\hline Class & $\begin{array}{c}\text { XI IPA } \\
\mathbf{1}\end{array}$ & $\begin{array}{c}\text { XI } \\
\text { IPA 2 }\end{array}$ & $\begin{array}{c}\text { XI } \\
\text { IPA 3 }\end{array}$ & $\begin{array}{c}\text { XI } \\
\text { IPA 4 }\end{array}$ \\
\hline Average Score & 73.12 & 79.77 & 72 & 71.76 \\
\hline Normality Testing & 0,164 & 0,102 & 0,072 & 0,156 \\
\hline $\begin{array}{l}\text { Homogeneity } \\
\text { Testing }\end{array}$ & \multicolumn{4}{|c|}{0.291} \\
\hline
\end{tabular}

Tabel I. The Result of Students' Average Score, Standard Deviation and Variance

of Reading Comprehension for Placement Test.

From the average score of the four classes, we can see that XI IPA 3 and XI IPA have nearly same of score. Thus, these classes are the sample classes of this research. To determine which was class acted as an experimental class and control class, the researcher did 
lottery. As the result, experimental class was XI IPA3 that taught by using Inquiry Chart Strategy and control class was XI IPA4 that taught by using Small Group Discussion Strategy. Last, the researcher determined that XI IPA 1 was as try out class, because the average score of such class was slightly higher than experimental and control class. Then, we could know that the data of population are normal and homogen because they were higher than significance level 0.05 . The researcher taught the experimental and control in class eight times (one times a week) including placement-test and post test. Each meeting spent 2 X45 minutes (90 minutes) study period.

In this research, the researcher used reading comprehension test to measure the students' reading comprehension in report text. It was developed by five indicators which proposed by King and Stanley (2004), they are: general information, specific information, meaning of word, social function, generic structure and grammatical features of report text.

\section{FINDING AND DISCUSSION}

The data needed in the research were collected from reading comprehension test. The data were gathered after the treatment. The summary of reading comprehension score of report text score can be seen as follow:

\section{Reading Comprehension Testing}

The test was administrated to the sample to get the data of students reading comprehension of report text. The reading comprehension test had been also discovered about the validity and the reliability before given to the sample. Then, Experimental and Control class were given the different treatment. The experimental class was taught by Inquiry Chart Strategy, and control class was taught by Small Group Discussion Strategy. The students taught through Inquiry Chart Strategy consisted of 34 students and the students taught through Small Group Discussion Strategy also consisted of 34 students. In scoring, the researcher gave 100 for the maximum score of each student. The data of students' score in experiment class and control class can be seen as follow:

\begin{tabular}{c|r|r|r|r|c|c|}
\hline Group & \multicolumn{1}{|c|}{ N } & Avg & Max & Min & SD & Var \\
\hline Exp & 34 & 82,05 & 95 & 65 & 6,86 & 47,14 \\
\hline Con & 34 & 74.70 & 90 & 55 & 8,87 & 78,69 \\
\hline
\end{tabular}

Table II. Summary of Students'

Reading Comprehension Score

in Experimental and Control Class

The table shows the average score is 82.05 , with the highest score is 95 , and the lowest score is 65 . Then, standard deviation is 6.86 and variance is 47.14 . In control class, The average score is 74.70 , with highest score is 90 , and the lowest score is 55 . Then, standard deviation is 8,87 and variance is 78,69 .
The result of students' score in reading comprehension can be illustrated by the data distribution curve below:

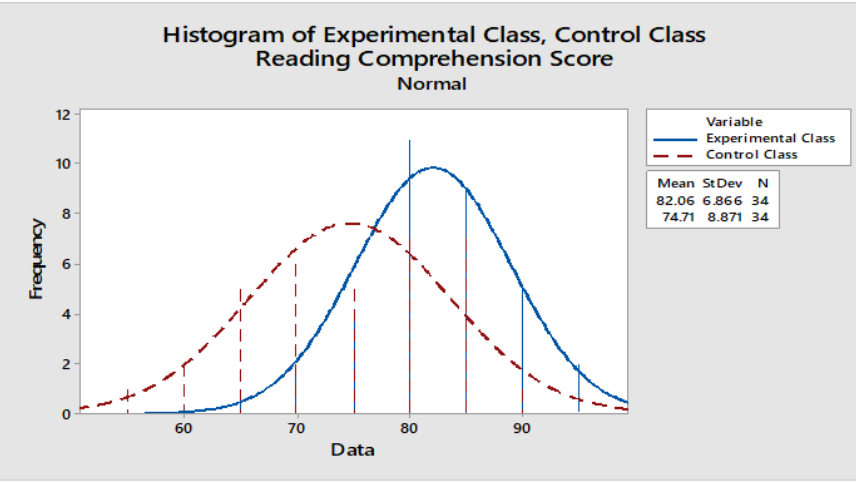

Chart 1. Frequency Distribution of

Students' Reading Comprehension Score for Experimental and Control Class

Based on the data above, we can see that most students taught by using Inquiry Chart Strategy gained higher score than those taught by using Small Group Discussion Strategy. It can be concluded that Inquiry Chart Strategy produces better result in teaching reading comprehension of report text.

\section{Hypothesis Testing}

In this research, hypothesis testing used t-test. In computing and processing the data, the researcher used SPSS 18 and manually. It can be seen in the following table:

\begin{tabular}{|c|c|}
\hline $\mathrm{t}_{\text {observed }}$ & $\mathrm{t}_{\text {.table }}$ \\
\hline 3.823 & 1,668 \\
\hline
\end{tabular}

Based on the table above, it can be seen that $t$ observed $>\mathrm{t}$ table. It means that, $\mathrm{HO}$ is rejected.

It can be concluded that Inquiry Chart Strategy produces better result towards students' reading comprehension of report text as compared to Small Group Discussion Strategy.

\section{Discussion}

From the result of first hypothesis, it could be seen that the average score of students' reading comprehension in report text which was taught by using Inquiry Chart Strategy was higher as compared to Small Group Discussion Strategy. It can be concluded that Inquiry Chart Strategy gave significant effect toward students' reading comprehension in report text. This finding was in line with the finding of the research which was conducted by Pariska (2013). She found that "the students who are taught by using Inquiry Chart Strategy have higher reading comprehension score in report text, than the students who are taught without using Inquiry Chart Strategy". It can be seen from there is significant different between pre-test and post-test in experimental class and pre-test and post-test in control class.

In this research, the researcher used texts from the book and internet. The researcher focused on one of the texts that were determined in Curriculum 2013 for eleven class of Senior High School, namely report text. It was based on Buehls' (2014) explanation that "in the use 
of Inquiry Chart Strategy, the teacher may select a topic studied in the curriculum". Here, the researcher decided the topic of report text in this research based on what is stated in English syllabus of class eleven of Senior High School point 3.6 and 4.9. In which, the topic of factual report text can be about people, animals, things, natural, and social phenomenon, related to another lesson in class eleven of Senior High School. Then, it was also be used in Small Group Discussion Strategy for control class. However, the researcher only used one text for control class, and two texts for experimental class.

In experimental class, Inquiry Chart Strategy involves the students to work in groups in doing the reading comprehension tasks. This strategy consisted of some steps such as generating four guided questions about a topic, distributing Inquiry Chart organizers and has students to record the questions in the appropriate spaces, encouraging students to think about, discuss, and record what they have already known about each questions, allowing time for students to read and answer the questions based on the resources texts, encouraging students to reflect information based on what they have already known and the texts, asking students to develop a summary of their finding. These activities were able to help students to comprehend better the report text, because it could give beneficial effect to create students' learning experience that makes them to be active participants in comprehending their reading.

Moreover, Inquiry Chart Strategy helped the students to enhance their reading comprehension, because it gave them the opportunities to active their prior knowledge and build active thinking about a topic. The students were trained to access what they have already known about a topic before they come to the text. It helped the students comprehend their reading easily, because it gives them the general information about the text before reading. It was in harmony with Moore, et al (2002) explanation that "in the use of Inquiry Charts strategy, the students reflect the topic on what they already known and it will influence how well and how deeply they can comprehend the given texts, because prior knowledge that reader brought to reading situation is a primary context that much needed in reading comprehension. In other word, Inquiry Chart Strategy asked the students to elicit their prior knowledge as the bridge to find out the information of the text. As the result, the students were more confidence to deepen their reading comprehension.

Through this process, Inquiry Chart Strategy supported the students to have better critical thinking in comprehending report text. The students were able to analyze and respond information of the text by integrating what they have already known about the topic and information that found in the texts. Then, the students learnt to evaluate information and find their own answer about a topic discussion. This activity helped the students to explore their thinking skill in learning reading comprehension. It was appropiate with Tarek (2013) explanation that "this activity deepens students' understanding and strengthens their critical thinking and reading skills". Thus, Inquiry Chart Strategy was able to lead students to have better reading comprehension, because it demanded the students to be more active in finding the needed information, so that the stuents were interested in learning reading comprehension activities. We can say that Inquiry Chart Strategy was a very useful strategy to build students' reading comprehension especially in report text. Based on the result of this research, it can be concluded that Inquiry Chart Strategy produces better result toward students' reading comprehension in report text.

Meanwhile, in Small Group Discussion Strategy for control class, the researcher divided students into some groups that consist of 3 or 4 students. Then, the researcher asked students to work in groups to discuss the given texts. Nevertheless, the learning activities were less related to the students' real world, so that the students were not able to develop their ideas in comprehending a text. They were only concentrated to the given text. In fact, to connect the real world of the students with the topic being taught is needed. Therefore, the researcher found some students tend to be passive in learning activities. They did not actively involve in the class participation. Besides, the discussion process was only dominated by the dominant students, although the researcher has given the job distribution or a description for each member of the group. In other word, the group discussion was dominated by the students who have good comprehension in learning reading. It was in the same manner with the disadvantages of Small Group Discussion Strategy who mentioned by Brookfield (1990) in Rahmat (2017) that "group work often involved smart students only". In this case, the other group members only relied on the leader of the group in finishing their task. They thought that if the leader of group gets the good score in reading comprehension task, they also get the same score in learning reading. It means that, they were only more attention to theirs' score in learning reading comprehension than comprehending about a text.

According to Brown (1988) "small group provides opportunities for students' initiation for face to face, give and take, for practice in negotiation of meaning for extended conversation exchanges". In this process, the students are expected to share the information that related to the topic. Besides, they are also needed to exchange the ideas in solving the problems they encountered during the processing task. However, the application of Small Group Discussion Strategy in the classroom of this research was not effective because the students preferred to discuss about another topic that was not related to reading material. When the students were asked to find the important ideas and factual information in text, there was only 1-2 students who is active in finishing the tasks privately without any discussion with other members, but the other members were counted on their work. It means that, Small Group Discussion Strategy may become an effective strategy if it is applied for high input students. Yet, if it is applied to low input students, it will be less effective, because low input students need learning activities that help them to know the information of text accurately. It can be concluded that Small Group Discussion Strategy did not 
produce better result toward students' reading comprehension of report text.

From the discussion above, it could be concluded that Inquiry Chart Strategy produces better result toward students' reading comprehension in report text as compared to Small Group Discussion Strategy.

\section{CONCLUSION}

Based on the research findings those were done for SMAN 12 Padang. It can be concluded that Inquiry Chart Strategy produces better result toward students' reading comprehension in report text as compared to Small Group Discussion Strategy. Inquiry Chart Strategy was able to help students to comprehend better the report text, because it could give beneficial effect to create students' learning experience that makes them to be active participants in comprehending their reading. Moreover, Inquiry Chart Strategy helped the students to enhance their reading comprehension, because it gave them the opportunities to active their prior knowledge and build active thinking about a topic. Through this process, Inquiry Chart Strategy supported the students to have better critical thinking in comprehending report text. We can say that Inquiry Chart Strategy was a very useful strategy to build students' reading comprehension especially in report text.

\section{REFERENCE}

Anna. (2013). The Implementation of Small Group Discussion Technique in Teaching Reading Analytical Exposition Text. English Department of Language and Arts, State University of Surabaya. E-Journal Unesa.

Andriyani. (2014). Teaching reading by Combining Inquiry Chart and Dictogloss Strategies For grade ix at senior high school. Vol 1, No 1 (2014): Jurnal Wisuda Ke 48 Mahasiswa Prodi Pendidikan Bahas Inggris.

Brown. (1988). Effective Teaching in Higher Education. London. Rout Ledge. 2004. Language Assessment: Principle and Classroom Practice. Second Edition. New York: Pearson Education, Inc.

Buehl. (2014). Classroom Strategies for Interactive Learning. Third Edition. Newark DE. The international Reading Association, Inc.

Ciptoharmi. (2014). The Effect of Inquiry Chart (i-Chart) Toward the Tenth Grade Students' Reading Comprehension at SMA Negeri 7 Kediri in Academic Year 2014 / 2015. English Department. University of Nusantara PGRI Kediri.

Crilly. (2002). Classroom Organization. http://www.myread.org/quide stages.html

Wednesday, May 17. 09.00. Pm.

Gay and Airisan. (2000). Educational Research: Competencies for Analysis and Application. New Jersey: Prentice Hall.inc

Hanifah, (2014). The Reading Comprehension of Report Text of the eleventh grade students of Sma Negeri 1 Mayong Jepara in Academic Year 2013/2014 Taught by Using Two Stay Two Stray. Departement of English Education Faculty of
Teacher Training and Education University of Muria Kudus.

King and Stanley. (2004). Teaching Reading Skill in a Foreign Language. Oxford: Oxford University Press.

Moore, et al. (2002). Struggling Adolescent Readers: A Collection of Teaching Strategies. Newark, Del : International Reading Association. http://www.worldcat.org/oclc/249234133

Noh Muhammad. (2013). Salinan Lampiran Permendikbud RI No: 69. Tahun 2013 Tentang Kerangka Dasar dan Struktur Kurikulum SMA/MA (Online). Http://4shared.com/retrived on May 28th

Pariska. (2013). The effect of Using Inquiry Chart (IChart) Strategy toward Reading Comprehension in Report Text of the Second Year Students at MA, Daarun Nahdhah Thawalib Bangkinang. Department of English Education, Faculty of Education and Teacher Training, State Islamic University of Sultan Syarif Kasim Riau, Pekanbaru.

Pugalee. (2015). Effective Content Reading Strategies to Develop Mathematical and Scientific Literacy: Supporting the Common Core State Standards and the Next Generation Science Standards. Rowman and Littlefield. United States of America.

Rahmad. (2017). The Effect of Stop Model and Learning Interest toward the students' Reading Comprehension of Report Text at Second Grade of SMAN 1 Burut Pelalawan Riau. English Education Section. Language Education Study Program. Graduate Program. State University of Padang.

Rahmat. (2017). Small Group Discussion Strategy Towards Students' Reading Comprehension of SMA Negeri 11 Bulukumba. Metathesis, Vol. 1, No. 2, Oktober 2017. STMIK Handayani Makassar rahmatppsunm14@gmail.com. Journal of English Language, Literature, and Teaching.

Rahmi. (2014). The Use of Discovery learning strategy in Teaching Reading Report Texts to Senior High School Students. English Department, FBS State University of Padang.

Snow. (2002). Reading for Understanding Toward an $R \& D$ Program in Reading Comprehension. New York: RAND Education.

Stewart and Rivera. (2007). Inquiry-Based Learning. Friday, August 11. 2017. 07.00 Pm. http://www.esf.edu.iq/seminar/documents/Inquiry \%20Based\%20Learning\%5B1\%5D.ppt

Ur. (1996). Discussion that World: Language Book for Language Teacher. London. Longman Group Limited. 